3. Булгакова Е.С. Языковые и речевые средства реализации и нарушения коммуникативных качеств речи "выразительность" и "логичность" в аспекте речевого воздействия: на материале защитительных речей Ф.Н. Плевако: Дисс... канд. филол. н. Орел, 2007. 274 с.

4. Ворожейкин Е.М. Биографическая справка // Судебные речи известных русских юристов: Сборник / Составитель Е.М. Ворожейкин; Отв. ред. М.М. Выдря. М.: Госюриздат, 1958. С. 819-820.

5. Ворожейкин Е.М. Предисловие // Судебные речи известных русских юристов: Сборник / Составитель Е.М. Ворожейкин; Отв. ред. М.М. Выдря. М.: Госюриздат, 1958. С. 5-18.

6. Землякова Н.В., Гарбовская Н.Б. Образные средства языка в выступлениях судебных ораторов как один из приемов эффективной коммуникации // Теория и практика общественного развития. 2018. № 6. С. 95-99.

7. Кони А.Ф. По делу об убийстве Филиппа Штрама. [Электронный ресурс]. Режим доступа: https://mir-knig.com/read_318451-38

8. Кони А.Ф. По делу о подлоге завещания капитана гвардии Седкова. [Электронный ресурс]. Режим доступа: https://mir-knig.com/read_181713-76

9. Кони А.Ф. По делу о подлоге завещания от имени купца Козьмы Беляева. [Электронный ресурс]. Режим доступа: https://mir-knig.com/read 318451-42

10. Кони А.Ф. По делу о подлоге расписки в 35 тысяч рублей серебром от имени княгини Щербатовой. [Электронный ресурс]. Режим доступа: https://mir-knig.com/read_181713-12

11. Мельник В.В. Искусство защиты в суде присяжных: Учебно-практическое пособие. М.: Дело, 2003. $480 \mathrm{c}$.

12. Наседкина О.Е. Лексико-стилистические средства экспрессии в адвокатских речах конца XIX начала XXI веков в аспекте речевого воздействия // Вектор науки ТГУ. 2013. № 1(23). С. 210-213.

13. Нелюбин Л.Л. Лингвостилистика современного английского языка: Учебное пособие. М.: МОПИ им. Н.К. Крупской, 1990.

14. Рубинштейн Е.А. Предисловие // Защитительные речи советских адвокатов. Ч. 1. М.: Изд-во СГУ, 2009. C. 4-14.

15. Сергеич П. (Пороховщиков П.С.) Искусство речи на суде. Тула: Автограф, 2000. 320 с.

16. Соловьева Т.А. Лексико-грамматические и стилистические особенности судебной речи второй половины XIX века: Дисс... канд. филол. н. Тула, 2000. 207 с.

17. Холев Н.И. Дело Максименко // Судебные речи известных русских юристов: Сборник / Составитель Е.М. Ворожейкин; Отв. ред. М.М. Выдря. М.: Госюриздат, 1958. С. 821-865.

18. Энциклопедический словарь-справочник. Выразительные средства русского языка и речевые ошибки и недочеты. Под ред. А.П. Сковородникова. М.: ФЛИНТА, 2011. 480 с.

19. Эффективное речевое общение (базовые компетенции): словарь-справочник. Под ред. А.П. Сковородникова. Члены редколлегии: Г.А. Копнина, Л.В. Куликова, О.В. Фельде, Б.Я. Шарифуллин, М.А. Южанникова. Красноярск: Изд-во Сибирского федерального университета, 2014. 882 c.

\title{
Волнянский А.Е., Семенова С.Н., Семенова А.Н. \\ Частота появления слов-помещений в тексте (на примере произведения Дж. Эскотта «Призрак замка Дженни» на английском языке)
}

ФГБОУ ВО «Кубанский государственный университет»

(Россия, Краснодар)

doi: 10.18411/lj-04-2021-186

\section{Аннотация}

В статье рассматривается узкий спектр вопросов, связанных с изучением слов, обозначающих помещения в английском языке. Исследование проведено на материале художественного произведения Джона Эскотта “The Ghost of Genny Castle" («Призрак замка Дженни») на английском языке. С помощью программ Microsoft Office Word была составлена таблица, и Excel построена диаграмма на которых отображены частота использования и процентное соотношения выделенных слов в тексте произведения и осуществлен анализ полученных данных. Необходимость проведения подобных исследований обусловлена расширением кругозора читателей при помощи современных технических средств, упрощающих изучение произведений на любом языке.

Ключевые слова: статья, анализ, художественное произведение, исследование, лексика, таблица, Джон Эскотт. 
Abstract

The article is devoted to the study of a narrow range of issues related to the research of words denoting types of buildings in English. The work is based on the material of John Escott's fiction "The Ghost of Genny Castle" in English. With the help of Microsoft Office Word program, a table was compiled, and - Excel program a diagram was built to show the use frequency and percentage of selected words in the text of the work. The obtained data were analyzed. The need for such research is due to the expansion of the readers' horizons due to modern technical means that simplify the study of different literature genres in any language.

Keywords: article, analysis, fiction, research, vocabulary, table, John Escott.

\section{Введение}

Мы продолжаем исследование текстов художественной литературы с целью систематизации полученных данных и выявления сходств и различий в лексических, грамматических и семантических отношениях.

Джон Эскотт - британский писатель, автор множества книг для детей и подростков. Именно с них он начинал свою карьеру, но сейчас он работает с более широкой аудиторией. Творчество писателя привлекло наше внимание и, в связи с этим было проведено исследование одного из его произведений художественной литературы “The Ghost of Genny Castle” («Призрак замка Дженни») на английском языке.

Тема исследования актуальна продуктивностью исследуемой лексики в художественной литературе в рамках различных филологических исследований.

Цель статьи - вычислить частоту появления слов-помещений в тексте художественного произведения Джона Эскотта "The Ghost of Genny Castle" на английском языке, классифицировать и описать полученные результаты.

Предмет исследования - художественное произведение Джона Эскотта "Тhe Ghost of Genny Castle" на английском языке [6].

Методологической базой послужили работы таких исследователей, как:

1) С.Ю. Преображенский, описывающий в своем труде проблемы межтекстовых связей в лингвистическом толковании художественных текстов [2, с. 788-793];

2) С.Н. Семенова, рассматривающая массив различных текстов на английском, русском и армянском языках, систематизируя полученные данные в мини-тезаурусах [3, с. 29; 4, с. 295; 5, с. 84].

Нами были применены такие методы исследования как:

1) сплошной выборки лексики из текста;

2) классификационный;

3) вычислительный.

\section{Анализ полученных результатов}

Исследование было проведено на материале произведения Джона Эскотта “Тhe Ghost of Genny Castle" на английском языке. Итак, в различных художественных произведениях присутствуют слова обозначающие помещения. По итогам работы с текстом, а точнее выявлением, подсчетом всех слов, обозначающих помещения и подсчетом повторений каждого из найденных слов получены данные, которые систематизированы и представлены нами в таблице (табл. 1).

Таблица 1.

Количественное и прочентное соотношение самых повторяемых слов

\begin{tabular}{|c|c|c|c|}
\hline № & Название & Количество & Соотношение в \% \\
\hline 1 & Castle & 42 & 40,7 \\
\hline 2 & Cottage & 20 & 19,4 \\
\hline 3 & Village & 7 & 6,7 \\
\hline 4 & Tower & 26 & 25,2 \\
\hline
\end{tabular}




\begin{tabular}{|l|c|c|c|}
\hline 5 & Home & 5 & 4,8 \\
\hline 6 & House & 1 & 0,9 \\
\hline 7 & Building & 2 & 1,9 \\
\hline & Итого: & $\mathbf{1 0 3}$ & $\mathbf{1 0 0}$ \\
\hline
\end{tabular}

Согласно показателям таблицы построена диаграмма (рис. 1), которая наглядно показывает превосходство в частоте использования автором произведения некоторых слов над другими в тексте.

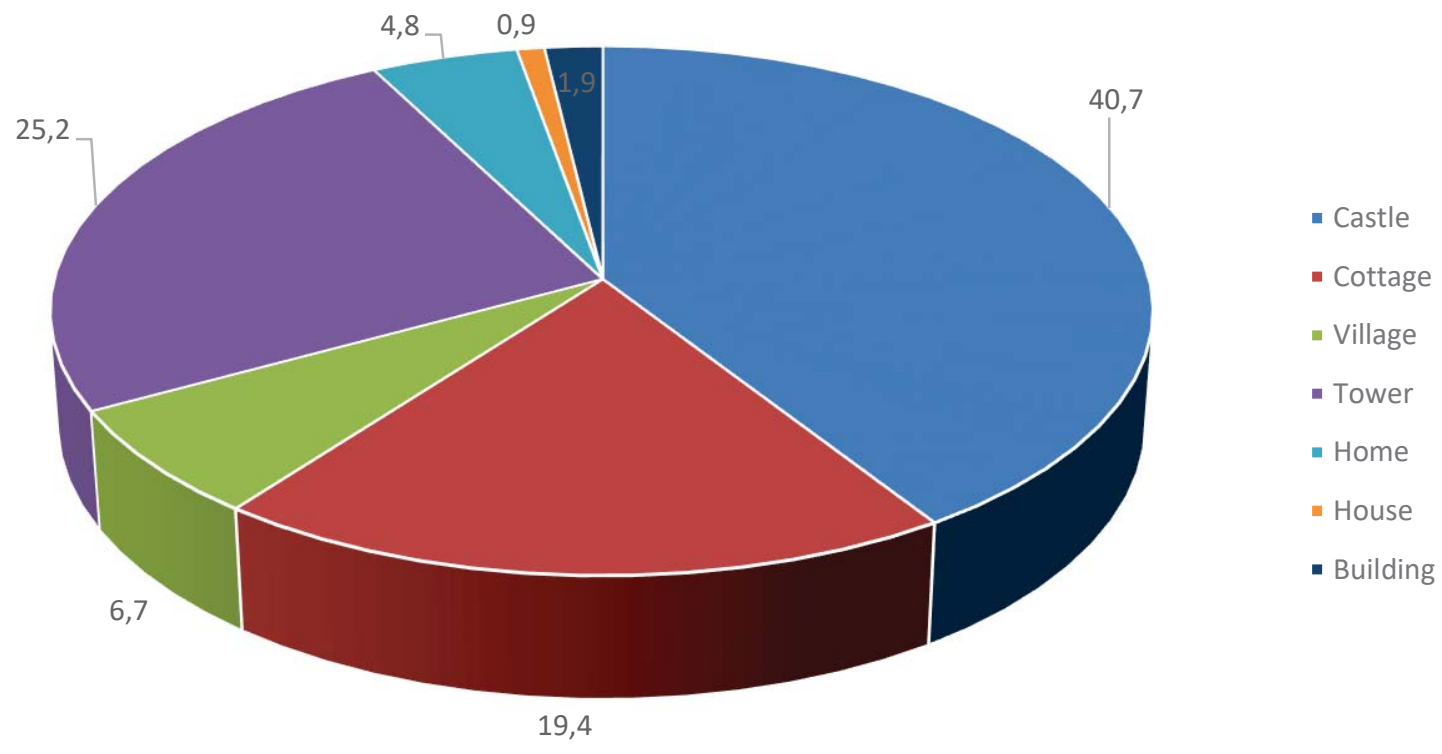

Рис 1. Процентное соотношение слов в тексте произведения

Рис. 1 демонстрирует диаграмму, на которой видно какие слова в исследуемом нами произведении повторяются чаще других и их процентное соотношение относительно других слов в тексте.

Благодаря научным взглядам, На Ван и Ярослава Кобылко, согласимся, что: «...художественный текст представляет собой поток сознания... повторяться и закрепляться будет именно то, что тревожит художника» [1] т.е. писателя произведения. Автор часто использовал повторение некоторых слов, таких как: "Castle" (Замок) - это самое часто повторяющее слово в тексте, писатель использовал его 42 раза в тексте (40,7\% от всех повторяемых слов), этим словом он подчеркивал значимость этого места для читателя, ведь этот замок является главным источником мистических событий.

Вторым по количеству повторений является слово “Тower” (Башня), оно так же, как и предыдущее подчеркивает значимость места, где развиваются события, оно повторяется 26 раз - это 25,2\%. Далее следует слово “Cottage" (Коттедж) - оно повторяется 20 раз в тексте произведения (19,4\% от общего количества слов). Этим 
словом автор подчеркивает, что место, где разворачиваются события небольшая деревня, где нет огромных зданий, а одни небольшие дома (коттеджи). Остальные слова составляют небольшой процент повторений, хотя они также являются способом подчеркивания мест развития событий.

\section{Заключение}

В ходе изучения материала произведения мы пришли к выводу, что самым повторяемым словом является "Castle” (Замок). Данное слово находится даже в составе названия произведения и именно в этом месте разворачивается основной сюжет рассказа, именно поэтому его так часто использовал автор.

Таким образом, следует отметить, что авторы многих произведений используют повторы слов для того, чтобы подчеркнуть то, на чем читателю следует заострить внимание. Поэтому данное исследование помогло нам выявить данный прием и определить часто повторяемые слова в тексте рассказа.

Мы считаем, что необходимость проведения подобных исследований обусловлена расширением кругозора читателей при помощи современных технических средств, упрощающих изучение произведений на любом языке.

В заключении хотелось бы подчеркнуть актуальность и важность подобного рода исследований для получения новых результатов и выводов. В будущем планируется дальнейшее детальное изучение текста этого произведения в лексикосемантическом отношении для выявления сходств и различий в оригинале и его переводах, выполненных разными профессиональными переводчиками.

$$
* * *
$$

1. На В., Кобылко Я. Метод текстового семантического поля как возможность системного подхода к изучению художественного текста: на материале романа И.С. Тургенева «Дворянское гнездо» // Вестник Российского университета дружбы народов. Серия: Теория языка. Семиотика. Семантика. 2020. T. 11. №3. С. 560-571. doi: 10.22363/2313-2299-2020-11-3-560-571.

2. Преображенский С.Ю. Проблема межтекстовых связей в лингвистическом толковании художественных текстов: аллюзия и цитация // Вестник Российского университета дружбы народов. Серия: Теория языка. Семиотика. Семантика. 2017. Т. 8. №4. С. 788-793. doi: 10.22363/2313-2299-2017-8-4-788-793.

3. Семенова С.Н. Тезаурус жанра рассказ как произведения художественной литературы (на материале рассказов Дж. Лондона «Безмолвие» и «Сын Волка» на английском, армянском и русском языках) // Филологические науки. Научные доклады высшей школы. М.: АЛМАВЕСТ, 2017. № 2. C. 28- 37. doi: 10.20339/PhS.2-17.028.

4. Семенова С.Н. Тезаурус жанра сказка (на материале произведения А.С. Пушкина «Сказка о рыбаке и рыбке» на русском, армянском и английском языках) // Вестник Российского университета дружбы народов. Серия: Теория языка. Семиотика. Семантика. 2017. Т. 8. №2. С. 293-300. doi: 10.22363/2313-2299-2017-8-2-293-300.

5. Шилов Г.С., Семенова С.Н., Резепова В.К. Сравнительно-сопоставительный анализ художественного текста (на примере сказки О. Уальда «Эгоистичный великан» на английском и русском языках) // Тенденции развития науки и образования. Самара: Изд. НИЦ «Л-Журнал», 2021. №70. Ч. 7. С. 82-85. doi: 10.18411/1j-02-2021-266.

6. Эскотт Дж. "The Ghost of Genny Castle" [Электронный ресурс] - Режим доступа: https://fobook.ru/the-ghost-of-genny-castle (дата обращения: 23.09.2020).

Гареева Г.Н.

Жанровые особенности башкирских повестей 1930-х годов

Башкирский государственный университет

(Россия, Уфа)

doi: 10.18411/lj-04-2021-187

Аннотация

В период формирования эпических форм национальной прозы к реалистическому изображению действительности башкирская литература шла путем 